\title{
ANALISIS KEBERLANJUTAN LILIFUK: TINJAUAN PERSEPSI MASYARAKAT LOKAL
}

\section{Sustainable Analysis of Lilifuk: Review Perceptions of Local Communities}

\author{
*Maharani Yulisti, Nendah Kurniasari dan Christina Yuliaty \\ Balai Besar Penelitian Sosial Ekonomi Kelautan dan Perikanan \\ Gedung Balitbang Kp I Lt. 4 \\ Jalan Pasir Putih Nomor 1 Ancol Timur, Jakarta Utara \\ Telp: (021) 64711583 Fax: 64700924 \\ "email: maharani2811@yahoo.com \\ Diterima 4 April 2014 - Disetujui 6 Juni 2014
}

\begin{abstract}
ABSTRAK
Peran serta masyarakat dalam pengelolaan sumber daya perikanan dalam bentuk kearifan lokal merupakan wujud tanggung jawab mereka dalam melestarikan sumber daya sehingga dapat memberikan manfaat berkelanjutan.Kearifan lokal tersebut bernama Lilifuk, yaitu kawasan di laut berbentuk kolam yang tergenang saat surut sehingga ikan terperangkap di dalamnya.Tulisan ini mengkaji persepsi masyarakat mengenai keberlanjutan Lilifuk di Kabupaten Kupang. Penelitian dilaksanakan di Desa Bolok dan Desa Kuanheum, Kecamatan Kupang Barat Kabupaten Kupang pada Oktober 2012 dengan menggunakan pendekatan kualitatif. Metode studi kasus dan triangulasi digunakan dalam penelitian ini. Wawancara mendalam dilakukan terhadaptetua adat, kepala desa, dan perwakilan lembaga swadaya masyarakat.Data persepsi masyarakat dikumpulkan dari 30 responden. Data dianalisis secara kualitatif dan kuantitatif. Hasil analisis persepsi menunjukkan bahwa sebesar 93,3\% masyarakat mengetahui tentang keberadaan Lilifuk, 60\% tahu sejarahnya, 93,3\% tahu lokasinya dan 26,7\% tahu batas-batasnya. Sebanyak 44\% masyarakat menyatakan otoritas pengambilan keputusan pengelolaan Lilifuk adalah pemiliknya.Keterlibatan Masyarakat dalam Lilifuk hanya sebagai pemanfaat saat Lilifuk dibuka (63\%). Manfaat Lilifukdapat diidentifikasikan sebagai berikut: menambah penghasilan, menjalin hubungan sosial, rekreasi, menjaga sumber daya ikan, menjaga lingkungan dan menjaga tradisi. Faktor-faktor yang mengancam keberlanjutan Lilifuk adalahlahan yang sempit, penurunan produksi ikan, pencemaran perairan dan tidak adanya penjagaan. Prioritas utama dalam menjaga keberlanjutan Lilifuk adalah (1) Menjaga dan melindungi serta memperbaiki kelestarian lingkungan; (2) Dukungan dan pengawasan pemerintah; (3) Menerapkan aturan dan sanksi hukum; (4) Meningkatkan kesadaran masyarakat mengenai kelestarian, dan; (5) Menggunakan alat tangkap ramah lingkungan.
\end{abstract}

Kata Kunci: Lilifuk, keberlanjutan, masyarakat lokal, persepsi

\section{ABSTRACT}

Community participation in the fish resources management in the form of local wisdom is a form of community responsibility to preserve the resources in order to ensure its sustainable benefits. This paper examined community perceptions about the local wisdom sustainability of Lilifuk management in Kupang district. The study was conducted in Bolok and Kuanheum villages, West Kupang, Kupang Regencyduring October 2012 using a qualitative approach. A case study and triangulation methods were used in this study. Indepth interviews were conducted to the elders, village leaders, and representatives of NGOs. Data of community perceptions were collected from 30 respondents. Data were analyzed by qualitative and quantitative. Based on the analysis of perception, $93.3 \%$ of people know about the existence of Lilifuk, 60\% know the history of Lilifuk, 93.3\% know the location of Lilifuk and $26.7 \%$ knew its limits. As many as $44 \%$ of people said that the owner has the decision-making authority on Lilifuk management. Community Involvement in Lilifuk is only as beneficiaries when Lilifuk is open (63\%). Benefits of Lilifuk were identified as factors: incomeincreasing, social relationships, recreation, fish resource preservation, environment conservation and tradition protection. Lilifuk is threated by factors such as a narrow area, fish production declining, water pollution and unprotected area. The main priorities in maintaining the sustainability of Lilifuk are: (1) Maintaining, protection and improving the environment; (2) Government supporting and supervision; (3) Applying the rules and legal sanctions; (4) Increasing public awareness of sustainability, and; (5) Using environmental friendly fishing gear.

Keywords: Lilifuk, sustainability, local community, perception 


\section{PENDAHULUAN}

Pengelolaan sumber daya alam merupakan upaya-upaya pelestarian dan perlindungan keanekaragaman biologi pada tingkat genetik, spesies dan ekosistem, serta menjamin kekayaan alam, binatang dan tumbuhan di seluruh Kepulauan Indonesia. Sumber daya alam yang lestari dapat menjamin keberlanjutan produksi dan pendapatan masyarakat yang pada akhirnya akan berdampak pada peningkatan kesejahteraan (Mitchell et al., 2000). Hal ini sejalan dengan pernyataan Fauzi (2004) bahwa pengelolaan sumber daya alam yang baik akan meningkatkan kesejahteraan umat manusia, dan sebaliknya pengelolaan sumber daya alam yang tidak baik akan berdampak buruk bagi umat manusia. Pengelolaan sumber daya alam yang arif dan berkelanjutan diperlukan untuk mengantisipasi peningkatan degradasi lingkungan.

Kearifan tradisional dalam masyarakat adat merupakan segala bentuk pengetahuan, keyakinan, pemahaman maupun wawasan serta adat istiadat atau etika masyarakat yang menuntun perilaku kehidupan mereka di dalam komunitas ekologisnya (Keraf, 2010). Seluruh kearifan lokal ini dihayati, dipraktekkan, diajarkan dan diwariskan dari satu generasi ke generasi lain yang membentuk pola perilaku manusia sehari-hari, baik sesama manusia maupun manusia terhadap alam. Keberadaan Lilifuk di Kabupaten Kupang merupakan suatu bentuk kearifan lokal pengelolaan sumber daya perikanan.

Meningkatnya jumlah penduduk dan kepentingan-kepentingan lain seperti faktorfaktor ekonomi menyebabkan tekanan terhadap sumberdaya laut dan ekosisitemnya. Selain itu, terjadi tekanan sosial dan ekonomi terhadap masyarakat akibat adanya kegiatan pemanfaatan sumber daya secara intensif oleh pihak-pihak tertentu atau perusahaan besar mengakibatkan sulitnya akses masyarakat terhadap sumber daya perikanan. Sehubungan dengan hal itu, upaya pengelolaan lingkungan terutama sumber daya pesisir dan laut merupakan langkah yang penting dan strategis untuk keberlanjutannya. Berbagai contoh pengelolaan sumber daya laut berbasis masyarakat berdasarkan hukum adat (kearifan lokal) di berbagai daerah di Indonesia yang secara tidak disadari justru menerapkan kaidah-kaidah konservasi sumber daya yang dapat menjaga keberlanjutan sumber daya tersebut.
Peran serta masyarakat dalam pengelolaan suatu daerah perlindungan laut berbasis masyarakat dalam bentuk kearifan lokal merupakan wujud tanggung jawab masyarakat dalam menjaga dan melestarikan sumber daya kelautan dan perikanan sehingga dapat memberikan manfaat bagi masyarakat sekitarnya. Pemanfaatan sumber daya tersebut harus menyelaraskan antara aktivitas manusia dengan kemampuan sumber daya yang menopangnya (Sugandhy \& Hakim, 2007). Persepsi masyarakat mengenai pengelolaan sumber daya perikanan didapatkan untuk mengetahui pentingnya kelestarian sumber daya perikanan dalam menopang kehidupannya. Kajian mengenai persepsi masyarakat terhadap suatu pengelolaan sumberdaya mutlak diperlukan untuk mengetahui sejauh mana peran masyarakat terhadap pengelolaan sumber daya perikanan tersebut. Persepsi masyarakat ini juga dilakukan untuk mengetahui posisi dan peran serta masyarakat di sekitar kawasan tersebut, apakah masyarakat menjadi penghalang bagi keberlanjutan kawasan konservasi, atau masyarakat justru dapat diharapkan memiliki peran aktif dalam pelestarian dan pengelolaan sumber daya perikanan tersebut. Tujuan dari tulisan ini adalah mengkaji persepsi masyarakat mengenai keberlanjutan Lilifuk di Kabupaten Kupang.

\section{METODOLOGI}

Tulisan ini merupakan bagian dari hasil penelitian yang penulis lakukan mengenai Kajian Kearifan Lokal Dalam Mendukung Kelestarian Sumber Daya, Peningkatan Produksi dan Pendapatan pada tahun 2012. Pendekatan kualitatif dan kuantitatif digunakan dalam penelitian ini. Kombinasi metode studi kasus dan triangulasi digunakan dalam penelitian ini yang memadukan pengamatan, wawancara dan analisis dokumen (Sitorus, 1998). Menurut Idrus (2009), studi kasus merupakan desain penelitian pada pendekatan kualitatif maupun kuantitatif yang mempelajari suatu individu maupun unit sosial tertentu secara mendalam yang bersifat alami, holistik, mengandung unsur budaya, serta memiliki pendekatan fenomologi. Kelebihan dari metode ini adalah dapat saling menutupi kelemahan antara satu metode tersebut dengan metode lainnya sehingga hasil yang diharapkan mengenai realitas sosial ini lebih valid menggambarkan kearifan lokal masyarakat kelautan dan perikanan dalam pengelolaan dan pelestarian sumberdaya Lilifuk dan mekanismenya. 


\section{Metode Pengumpulan Data}

Penelitian dilakukan di Desa Bolok Kecamatan Kupang Barat Kabupaten Kupang, Nusa Tenggara Timur pada Bulan Oktober 2012. Data yang dikumpulkan dalam penelitian ini terdiri dari data primer dan data sekunder. Data sekunder diperoleh dari analisis dokumen yang bersifat hasil penelitian seperti buku, makalah dan skripsi. Untuk pengumpulan data primer, dilakukan dengan pengamatan dan wawancara mendalam (indepth interview) serta wawancara yang dipandu dengan instrumen penelitian berupa kuesioner. Pengamatan yang dilakukan dalam penelitian ini adalah kondisi sosial kultural kemasyarakatan dan kondisi sumber daya perikanan. Wawancara dilakukan untuk mendapatkan informasi mengenai pengelolaan sumber daya, kearifan lokal, serta persepsi masyarakat. Analisis dokumen dilakukan terhadap hasil-hasil penelitian sebelumnya yang terkait dengan kajian ini seperti skripsi, jurnal dan dokumen lainnya.

Informasi mengenai pengelolaan sumber daya Lilifuk dikumpulkan melalui wawancara mendalam dengan tokoh masyarakat seperti tetua adat, kepala desa, dan perwakilan lembaga swadaya masyarakat dengan menggunakan pedoman wawancara/ topik data dan menggunakan alat bantu rekam. Penentuan informan dilakukan secara purposif dimana informan ditentukan karena alasan khusus. Tetua adat dipilih sebagai informan untuk menjawab pertanyaan terkait sejarah, latar belakang dan pengetahuan mengenai Llilifuk. Kepala desa membantu dalam menjawab pertanyaan seputar desa dan sejarahnya serta peran pemerintah dalam Lilifuk. Perwakilan lembaga swadaya masyarakat menjadi informan dalam penelitian dengan alasan peran serta yang besar dalam pembuatan Peraturan Desa (PERDES) terkait Lilifuk.

Data persepsi masyarakat dikumpulkan dari 30 contoh masyarakat Desa Bolok sebagai responden yang dipilih secara acak terkait dalam pemanfaatan dan pendayagunaan sumber daya perikanan Lilifuk di Kupang Barat Pegumpulan data persepsi menggunakan instrumen penelitian berupa kuesioner.

\section{Metode Analisis Data}

Data yang diperoleh dianalisis dengan kombinasi metode kualitatif dan kuantitatif. Hasil wawancara indepth interview dianalisis dengan cara deskriptif interpretatif, yaitu peneliti memaparkan data secara keseluruhan kemudian menginterpretasikan dengan melalui tahapan sebagai berikut :

1. Pengorganisasian data, pada proses ini data dipilih dan diurutkan yang sesuai dengan kajian yang dilakukan

2. Pemaknaan dengan ciri signifikansi, selanjutnya dihubungkan dengan idealisasi deskripsi yang dihasilkan disesuaikan dengan teori

3. Mendeskripsikan data sebagai hasil analisis dalam bentuk laporan

4. Membuat simpulan tentang hasil analisis

5. Verifikasi atau memeriksa kembali

Data mengenai persepsi yang diperoleh dari hasil wawancara dianalisis secara kuantitatif dengan menggunakan statistik sederhana.

\section{HASIL DAN PEMBAHASAN}

\section{Potensi Sumber Daya Perikanan}

Kabupaten Kupang memliki sumber daya pesisir dan laut yang cukup besar diantaranya hutan mangrove, padang lamun, terumbu karang, berbagai jenis ikan laut, krustasea serta rumput laut. Berdasarkan hasil pengamatan, masyarakat memanfaatkan sumber daya tersebut sebagai bahan makanan dan sumber mata pencahariannya. Hasil tangkapan masyarakat nelayan umumnya digunakan sebagai bahan makanan keluarga dan sisanya dijual untuk mendapatkan uang.

Desa Bolok merupakan salah satu desa yang berada di kawasan pesisir Kecamatan Kupang Barat Kabupaten Kupang Nusa Tenggara Timur. Desa Bolok memiliki lokasi yang strategis dengan perairan pantai yang cocok untuk budidaya rumput laut sekaligus penangkapan ikan pelagis dan ikan karang. Hal ini yang menjadikan sebagian besar masyarakat Desa Bolok bermata pencaharian sebagai nelayan.

Melimpahnya ikan karang di sekitar Desa Bolok dikarenakan masih banyaknya terumbu karang di pesisir pantai desa, meskipun dalam kondisi yang rusak. Terumbu karang yang terdapat di pesisir Desa Bolok terdiri dari beberapa jenis yaitu karang lunak, karang bercabang dan karang otak. Selain itu, masih terdapat banyak padang lamun diantaranya jenis Thalisia hempricii dan Enhalus acaroides. Tutupan lamun yang sangat tinggi juga mejadikan potensi ikan karang yang cukup besar. Potensi sumber daya ikan karang 
di pesisir Desa Bolok yang merupakan daerah pasang surut tersebut diantaranya ikan Beronang (Siganus spp.), Alu-alu (Sphyranidae), Kerapu (Ephinephelus spp.), dan Peperek (Leigonathidae).

Terumbu karang yang berada di sekitar perairan Desa Bolok sudah mengalami kerusakan. Hal ini disebabkan oleh aktivitas manusia seperti penangkapan ikan terutama penangkapan pada saat surut. Selain itu juga kerap dilakukan pengeboman oleh nelayan yang dianggap mudah karena tidak memakan biaya yang banyak serta menghasilkan banyak tangkapan dalam waktu singkat. Penambangan karang juga sering dilakukan masyarakat untuk dijadikan sebagai bahan bangunan seperti dermaga, rumah dan pagar, pembuatan kapur serta pembuatan jalan.

\section{Kondisi Sosial Ekonomi Masyarakat}

Masyarakat Kupang terdiri dari beberapa suku diantaranya suku Tetun, Helong, Flores, dan Rote. Penduduk desa Bolok terdiri dari berbagai suku asli Nusa Tenggara Timur (NTT) dan berbagai suku dari luar NTT. Dominasi suku yang ada di Desa Bolok berasal dari suku Helong. Sekarang, dari suku-suku tersebut terdapat 13 marga yang mendiami desa tersebut yang awalnya hanya 7 marga asli. Meskipun terdapat berbagai etnis dengan berbagai budaya yang berbeda, namun masyarakat desa ini tinggal secara akur dan damai hidup berdampingan dalam kehidupan sehari-hari (Boikh, 2010).

Meskipun diketahui dari Data Monografi Desa Bolok (2010) bahwa mata pencaharian penduduknya adalah petani sawah tadah hujan $(38,8 \%)$ dan hanya $14,2 \%$ merupakan nelayan, namun mereka lebih menggantungkan hidupnya sebagai nelayan dalam pemenuhan proteinnya. Mereka menangkapikan setiap hariuntukmemenehi kebutuhan protein keluarga, tidak untuk dijual. Selain itu, 38,8\% petani tersebut dapat berganti pekerjaan sebagai nelayan atau pembudidaya rumput laut pada saat musim kemarau. Lebih lanjut, untuk memenuhi kebutuhan hidupnya masyarakat melakukan pekerjaan sesuai dengan kondisi atau musim yang ada yaitu pada musim hujan mengerjakan sawah tadah hujan, sedangkan pada musim kemarau melakukan pekerjaan sebagai nelayan. Masyarakat juga memiliki pekerjaan sampingan sebagai tukang ojek, penggali tanah dan buruh di pelabuhan.
Pekerjaan masyarakat yang sangat dipengaruhi oleh musim ini menyebabkan pendapatan atau penghasilan masyarakat seharaihari cukup kecil. Penghasilan ini rata-rata hanya untuk mencukupi kebutuhan makan sehari-hari saja. Misalnya pedagang atau buruh hanya mendapatkan upah sebesar Rp. 400.000 per bulannya. Nikijuluw (2001) menyatakan bahwa sebagian masyarakat nelayan pesisir adalah pengusaha skala kecil dan menengah yang bersifat subsisten yang menjalani usaha dan kegiatan ekonominya hanya untuk memenuhi kebutuhan jangka waktu yang sangat pendek sehingga hasilnya hanya cukup untuk menghidupi keluarganya saja.

Mayoritas penduduk desa ini adalah penganut agama Kristen Protestan. Sebagian kecil masyarakat memeluk agama Islam dan Kristen Katolik. Namun begitu, kerukunan beragama tetap terjalin yang dibuktikan dengan tidak pernah adanya konflik diantara penganut agama yang berbeda.

\section{Kearifan Lokal Pengelolaan Sumberdaya Laut bernama Lilifuk}

Pengelolaan sumber daya laut yang dikenal oleh masyarakat Kupang adalah Lilifuk. Lilifuk merupakan suatu kawasan di perairan laut yang berbentuk kolam yang tergenang pada saat air laut surut. Pada saat surut ini ikan banyak yang terperangkap di dalamnya. Karena itu, masyarakat kemudian mengelola sumber daya ini untuk ditutup dari aktivitas penangkapan ikan sehari-hari dan dibuka ${ }^{1}$ untuk sekali atau dua kali dalam setahun sesuai dengan kesepakatan untuk dapat dimanfaatkan. Lilifuk tersebut merupakan hak milik dari suatu suku tertentu dengan pengelolaannya dilindungi oleh hukum adat.

Lilifuk yang ada di Kabupaten Kupang terdapat 3 buah yaitu Lilifuk Baimusu dan Lilifuk Gatal di Desa Bolok, serta Lilifuk Baineo di Desa Kuanheum. Batas-batas wilayah Lilifuk yang ditutup sebgai daerah konservasi yaitu sejajar dengan garis pantai dengan luas: a) Lilifuk Gatal: $200 x$ 100 m, b) Lilifuk Gatal: 370 x 30 m, dan c) Lilifuk Baineo: $100 \times 50 \mathrm{~m}$. Batas-batas wilayah tersebut juga diberi tanda. Awalnya tanda yang diberikan berupa batu. Namun karena batu-batu tersebut sering dibongkar pada saat dibuka, maka batas tersebut diganti dengan menggunakan kayu.

\footnotetext{
1Dibuka artinya bahwa sumber daya Lilifuk tersebut dapat diakses dan dimanfaatkan sepenuhnya oleh masyarakat dengan cara penangkapan ikan yang ada di dalamnya
} 
Tabel 1. Karakteristik Responden Berdasarkan Umur, Pendapatan, Suku, Tingkat Pendidikan dan Mata Pencaharian Utama di Desa Bolok, Kupang Barat, 2012.

Table 1. Characteristics Of Respondent By Age, Income, Ethnicity, Level of Education and Main Livelihood in The Bolok Village of West Kupang, 2012.

\begin{tabular}{|c|c|c|}
\hline $\begin{array}{l}\text { Nomorl } \\
\text { Number }\end{array}$ & $\begin{array}{l}\text { Kategori/ } \\
\text { Category }\end{array}$ & $\begin{array}{l}\text { Persentase Responden/ } \\
\text { Percentages of Respondent } \\
(\%) n=30\end{array}$ \\
\hline \multirow[t]{4}{*}{1} & Umur/Age & \\
\hline & $<25$ tahun/ less than 25 years old & 3.33 \\
\hline & 25-64/ between 25 to 64 & 90.00 \\
\hline & $>64 /$ more than 64 years old & 6.67 \\
\hline \multirow[t]{4}{*}{2} & Pendapatan / Income & \\
\hline & $<$ Rp. 1 juta/ Less than IDR 1 million & 93.33 \\
\hline & Rp. 1 - 2 juta/ Between IDR $1-2$ million & 6.67 \\
\hline & > Rp. 2 juta/ More than IDR 2 million & 0.00 \\
\hline \multirow[t]{6}{*}{3} & Suku / Ethnic & \\
\hline & Helong & 76.67 \\
\hline & Sumba & 10.00 \\
\hline & Sabu & 3.33 \\
\hline & Timor & 6.67 \\
\hline & Alor & 3.33 \\
\hline \multirow[t]{6}{*}{4} & Tingkat pendidikan / Level of education & \\
\hline & Tidak sekolah/ No formal education & 10.00 \\
\hline & SD / Elementary School & 43.33 \\
\hline & SMP/ Junior High School & 13.33 \\
\hline & SMA/ High School & 26.67 \\
\hline & Universitas/University & 6.67 \\
\hline \multirow[t]{5}{*}{5} & Mata pencaharian utama / Main livelihood & \\
\hline & Nelayan / Fishermen & 43.33 \\
\hline & Petani / Farmers & 30.00 \\
\hline & $\begin{array}{l}\text { Pegawai atau wiraswasta / Employees or } \\
\text { Entrepreneurs }\end{array}$ & 10.00 \\
\hline & Lainnya / Others & 16.67 \\
\hline
\end{tabular}

Sumber: Data primer diolah (2012) / Sources: Primary data proceed (2012)

Kepemilikan Lilifuk oleh suatu suku tertentu adalah karena sejarah awalnya ditemukan wilayah tersebut oleh salah satu anggota suku tersebut sehingga dapat diklaim sebagai miliknya secara adat. Kesepakatan untuk menutup daerah tersebut dilakukan atas keinginan bersama dan diprakarsai oleh tokoh adat, pemerintah desa, tokoh agama serta masyarakat. Suku Holbala merupakan suku yang menguasai Lilifuk di Desa Bolok saat ini.

Komponen masyarakat yang berperan dalam kearifan lokal pengelolaan Lilifuk terbagi dalam 5 unsur yaitu tokoh agama, tokoh adat, pemerintah desa, masyarakat dan orang luar desa.
Tokoh adat memiliki peran sebagai penjaga sumber daya tersebut khususnya ikan yang ada di dalam Lilifuk serta membantu pemerintah desa dalam menghimpun infrmasi tentang adanya gangguan pencurian ikan di dalam wilayah tersebut. Tokoh agama dan pemerintah desa bersama-sama memiliki peran sebagai pengambil kebijakan, pertimbangan serta pemberian dukungan di dalam penerapan aturan yang sudah dibuat. Pemerintah desa juga berperan dalam penyebaran informasi kepada masyarakat luas saat waktunya Lilifuk dibuka. Masyarakat memiliki peran menjaga daerah tersebut dan mentaati peraturan yang sudah dibuat dalam rangka Lilifuk tersebut. 
Tabel 2. Pemenuhan Unsur-unsur Hak Ulayat pada Lilifuk di Kabupaten Kupang, tahun 2012. Table 2. Compliance Elements of Communal Property Right to Lilifuk in Kupang, 2012.

\begin{tabular}{|c|c|c|}
\hline $\begin{array}{l}\text { Nomorl } \\
\text { Number }\end{array}$ & $\begin{array}{c}\text { Unsur-unsur Hak Ulayat/ } \\
\text { Elements of Communal } \\
\text { Property Right }\end{array}$ & $\begin{array}{c}\text { Fakta/ } \\
\text { Evidance }\end{array}$ \\
\hline 1 & $\begin{array}{l}\text { Ada sekelompok/ persekutuan } \\
\text { (masyarakat) hukum adat yang } \\
\text { mendiami daerah tertentu } \\
\text { There are group / community } \\
\text { (society) customary law inhabited a } \\
\text { particular area }\end{array}$ & $\begin{array}{l}\text { Ada sekelompok masyarakat berdasarkan } \\
\text { sistem marga (marga Baimusu, marga } \\
\text { Holbala-Buitbesi-Klapeka, dan marga } \\
\text { Baineo) yang mempunyai wilayah di dekat } \\
\text { Lilifuk (Kupang) sebagai pemukiman dan } \\
\text { tempat nafkah / There are group of people } \\
\text { based on the clan system (Baimusu clan, } \\
\text { Buitbesi-Holbala-Klapeka clan, and Baineo } \\
\text { clan) having areas near Lilifuk (Kupang) as } \\
\text { settlements and livelihood }\end{array}$ \\
\hline 2 & $\begin{array}{l}\text { Masyarakat membuat dan } \\
\text { menciptakan serangkaian peraturan } \\
\text { peraturan yang menjadi pedoman } \\
\text { bagi setiap anggota persekutuan } \\
\text { atau } \\
\text { Masyarakat / } \\
\text { Community develops laws and } \\
\text { creates a set of rules as guidances }\end{array}$ & $\begin{array}{l}\text { Terdapat peraturan mengenai } \\
\text { pemanfaatan Lilifuk (meskipun tidak } \\
\text { tertulis) serta larangan menjualnya tanpa } \\
\text { ijin dari Kepala Suku / } \\
\text { There are regulations on the use of } \\
\text { Lilifuk (though not written) as well as the } \\
\text { prohibition to sell it without the permission } \\
\text { of the Chief }\end{array}$ \\
\hline
\end{tabular}

Memenuhi/

Conform for each member of the responding community.

Masyarakat hukum adat tersebut berhak menguasai atas tanah, air dengan segala macam isinya. Hak tersebut merupakan hak tertinggi di dalam masyarakat hukum adat dan tidak dapat dipecah-pecahkan atau dipindahtangankan /

Indigenous and tribal peoples are entitled to retain the land, water with all kinds of content. These rights is the highest indigenous peoples, can not be parted or transferred

Obyek yang dikuasai adalah tanah, air, sungai-sungai, pantai, tumbuhtumbuhan liar (pohon-pohon kayu) dan satwa-satwa liar/

Controlled objects are soil, water, rivers, coast, wild herbs (the trees) and wild animals

Obyek tersebut untuk keperluan masyarakat hukum dan anggotaanggotanya serta untuk keperluan orang luar yang pemanfaatannya terbatas dengan membayar uang pemasukan (retribusi atau recognitie/ The object is for the purposes of community and its members and so the outsiders, however, limited access is applied by paying cash income (retribution or recognitie)
Marga Baimusu menguasai perairan Lilifuk Baimusu, marga Holbala-Buitbesi-Klapeka menguasai Lilifuk Gatal, dan marga Baineo menguasai Lilifuk Kuanheun, yang berdasarkan batas-batas alamiah (Lilifuk merupakan kolam ikan di pantai dengan batas-batas yang sudah terbentuk secara alamiah)/

Baimusu clan controlled waters Lilifuk Baimusu, clan-Buitbesi Holbala-Klapeka master Lilifuk Itching and clan master Baineo Lilifuk Kuanheun, based on natural boundaries (Lilifuk is a fish pond on the beach with boundaries naturally formed)

Disamping wilayah yang dikuasai, juga adanya penguasaan atas sumberdaya alam seperti ikan dan rumput laut/ In addition to controlled areas, there as well as the control of natural resources such as fish and seaweed

Masyarakat memanfaatkan Lilifuk sebagai sumberdaya untuk peningkatan ekonominya. Orang luar memanfaatkannya dengan harus membayar retribusi pada saat dibuka/panen dengan membayar Rp. 2.500 per orang/ Lilifuk people use as a resource for economic gain. Outsiders use it must pay a fee at the time of opening / harvest by paying IDR. 2,500 per person
Memenuhi/ Conform

Memenuhi/ Conform

Memenuhi/ Conform 
Penangkapan ikan pada saat dibukanya Lilifuk dilakukan oleh masyarakat desa maupun dari luar desa tersebut. Penangkapan ikan tersebut biasanya dilakukan dalam dua hari tergantung dari keputusan pemilik Lilifuk. Pembukaan Lilifuk biasanya dimulai dengan pesta adat dan ritual agama sebelum dilakukannya panen ikan di wilayah tersebut.

Lilifuk merupakan suatu bentuk hak ulayat laut. Hak penguasaan masyarakat hukum atas tanah, air sungai, pantai, tumbuh-tumbuhan liar, satwa liar di dalam lingkungan guna kepentingan masyarakat hukum sendiri dan anggota-anggotanya serta orang luar yang membayar retribusi untuk itu dinamakan hak ulayat (Hanaf, 1994 dalam Yulianto, 2008). Hal ini diperkuat oleh UU No. 22 Tahun 1999 yang merupakan kekuatan hukum yang mengakui eksistensi institusi lokal yang ada di beberapa daerah dalam mengelola sumber daya ikan.

Lilifuk merupakan salah satu pengelolaan sumber daya perikanan Community Based Management (CBM). Menurut Nikijuluw (2002), CBM merupakan suatu proses pemberian wewenang, tanggung jawab dan kesempatan kepada masyarakat untuk mengelola sumber daya kelautan dan perikanan sendiri dengan memperhatikan kebutuhan, keinginan, tujuan dan aspirasinya.

\section{Persepsi Masyarakat terhadap Pengelolaan Sumber daya Lilifuk}

Persepsi masyarakat mengenai pengelolaan sumber daya perikanan difokuskan pada sikap dan anggapan masyarakat terhadap sumber daya Lilifuk dan pengelolaannya. Hasil penelitian menunjukkan bahwa perhatian dan pengetahuan mengenai keberadaan Lilifuk sangat baik. Hal ini terlihat dari hasil survey bahwa masyarakat mengetahui keberadaan Lilifuk, sejarah pembentukan dan lokasi Lilifuk (Tabel 3).

Masyarakat atau responden mengetahui keberadaan Lilifuk dengan berbagai persepsinya masing-masing. Hal ini terbukti dengan jawaban responden mengenai arti dari Lilifuk bermacammacam diantaranya:

- Kolam ikan (16,7\%)

- Tempat atau kolam berlindungnya ikan yang dilindungi $(6,7 \%)$

- Kolam ikan yang pemiliknya adalah sub suku tertentu saja (dikelola oleh adat) $(40 \%)$

- Suatu tempat/kolam ikan alami di laut saat air surut yang dikelola secara adat untuk dapat dipanen pada waktunya $(33,3 \%)$

- Pelestarian budaya lokal $(3,3 \%)$

Sejarah mengenai Lilifuk umumnya diketahui masyarakat dari orang tua, masyarakat, dan kerabat. Menurut persepsi masyarakat, sejarah Lilifuk:

- Lilifuk diwariskan oleh leluhur sejak tahun 1950 hingga sekarang dan dijaga oleh beberapa suku, dan kemudian pada saat panen maka akan dipanen oleh seluruh masyarakat sekitar melalui penyebaran undangan

Tabel 3. Persepsi Masyarakat Mengenai Keberadaan, Sejarah dan Lokasi serta Batas-batas Lilifuk di Kabupaten Kupang, Tahun 2012.

Table 3. Public Perception Regarding the Presence, History, Location and Boundaries of Lilifuk at Kupang Regency, 2012.

\begin{tabular}{|c|c|c|c|c|}
\hline \multirow{2}{*}{$\begin{array}{l}\text { Nomorl } \\
\text { Number }\end{array}$} & \multirow{2}{*}{$\begin{array}{l}\text { Daftar Pertanyaan/ } \\
\text { Question List }\end{array}$} & \multicolumn{3}{|c|}{$\begin{array}{c}\text { Persentase Jawaban / } \\
\text { Percentage of Responses (\%) }(n=30)\end{array}$} \\
\hline & & Ya/Yes & $\begin{array}{l}\text { Tidak tahul } \\
\text { Do not know }\end{array}$ & $\begin{array}{c}\text { Tidak } \\
\text { menjawab/ } \\
\text { No answer }\end{array}$ \\
\hline 1 & $\begin{array}{l}\text { Apakah anda tahu tentang Lilifuk? } \\
\text { Do you know about Lilifuk? }\end{array}$ & 93.3 & 6.7 & - \\
\hline 2 & $\begin{array}{l}\text { Apakah anda tahu sejarah Lilifuk?/ } \\
\text { Do you know the history of Lilifuk? }\end{array}$ & 60 & 40 & - \\
\hline 3 & $\begin{array}{l}\text { Apakah anda tahu lokasi Lilifuk?/ } \\
\text { Do you know the location of Lilifuk? }\end{array}$ & 93.3 & 6.7 & - \\
\hline 4 & $\begin{array}{l}\text { Apakah anda tahu batas wilayah Lilifuk? I Do } \\
\text { you know the boundaries of Lilifuk? }\end{array}$ & 26.7 & 53.3 & 20 \\
\hline
\end{tabular}

Sumber: Data primer diolah (2012) / Sources: Primary data proceed (2012) 
- $\quad$ Lilifuk sudah ada atau ditemukan sejak tahun 1960-an oleh para orang tua (suku tertentu) yang kemudian dijaga dan diwariskan kembali ke generasi penerusnya hingga sekarang

- Lilifuk dianggap sebagai sebuah kolam yang sudah ada sejak dahulu untuk menangkap ikan dan kemudian dijaga oleh suku-suku dan kemudian diklaim menjadi milik mereka

- Awalnya Lilifuk hanyalah sebuah kolam alami tetapi kolam tersebut memberi hasil yang memuaskan kepada masyarakat setempat namun beberapa orang yang berasal dari suku yang berbeda saling membantu untuk menjaga kolam alami tersebut dengan diberi pembatas atau dipagari dengan batu karang dan pada waktu panen Lilifuk dibuka oleh para pemiliknya dengan mengundang masyarakat sekitar untuk secara bersamasama memanen hasil (ikan) yang ada di kolam

- Lilifuk merupakan suatu peninggalan dari suku Baimusu dan sampai sekarang dilanjutkan oleh keturunannya sampai sekarang dan dilindungi oleh pemerintah dan adat

Persepsi masyarakat terhadap kepemilikan Lilifuk sekarang dibandingkan dulu adalah bahwa:

- Lilifuk merupakan warisan dari orang tua pada zaman dahulu (suku-suku tertentu) yang kemudian sekarang ini telah diwariskan kepada anak dan cucu mereka sebagai generasi penerus

- Pemiliknya adalah beberapa suku dari suku helong di Desa Bolok

- Pemilik Lilifuk adalah orang-orang atau suku-suku yang menjaga dan menemukan Lilifuk sejak dahulu yang sekarang ini diwariskan kepada anak dan cucu mereka sendiri

- Kepemilikan Lilifuk dulu dan sekarang tetap

- Kepemilikan tetap seperti dulu tetapi terkesan tidak terpelihara secara baik

- Dulu lebih bagus dari sekarang

- Luasnya kurang lebih 250 x $100 \mathrm{~m}^{2}$, kepemilikan Lilifuk dikelola oleh keturunan dari suku Baimusu dari dulu sampai sekarang
Aturan dan sanksi diterapkan dalam pengelolaan sumber daya Lilifuk ini. Aturan yang terdapat dalam pengelolaan ini diantaranya tidak boleh mengambil hasil laut apapun yang terdapat di dalam wilayah Lilifuk, penggunaan alat tangkap yang dibolehkan pada saat buka Lilifuk adalah alat tangkap yang ramah lingkungan (serok dan tombak), serta mekanisme keikutsertaan dalam waktu buka Lilifuk yaitu membayar biaya masuk sebesar Rp. 2.500 per orang. Sanksi yang diterapkan bila terjadi pelanggaran diantaranya berupa uang sebesar $\mathrm{Rp}$. 50.000 bagi masyarakat desa dan Rp. 250.000 bagi masyarakat di luar desa. Selain itu itu dikenakan denda babi/kambing, beras dan sarung. Selain itu itu dikenakan denda babi/kambing, beras dan sarung.

Otoritas pengambilan keputusan berkaitan erat dengan distribusi hak dalam pengelolaan sumber daya perikanan Lilifuk. Hak penguasaan Lilifuk dipegang oleh pemilik dan aparat desa, namun otoritas penentuan waktu pembukaan (panen) atau penutupan Lilifuk tersebut adalah hak pemilik beserta keluarganya dan aparat desa hanya mengesahkan dan menyebarkan informasi saja. Peran masyarakat dalam perlindungan sumber daya adalah mengawasi dan memelihara sumber daya laut dan pesisir. Begitu pula dalam hak pemindahtanganan Lilifuk sepenuhnya ada di pihak pemilik atas sepengetahuan pemerintah desa. Pemindahtanganan ini pernah terjadi pada Lilifuk Baimusu dimana awalnya dimiliki oleh marga Laiskodat, namun dengan pertimbangan kekeluargaan dan kepentingan kedua belah pihak kemudian disepakati untuk dipindahtangankan kepada marga Baimusu.

Apakah mekanisme pengambilan keputusan dalam pengelolaan lilifuk sudah tepat?. 10\% responden menyatakan bawa pengambilan keputusan sudah tepat, namun sebanyak $73 \%$ responden menyatakan tidak tepat, karena masyarakat tidak terlibat dalam mempertimbangkan keputusan-keputusan mengenai Lilifuk. Hanya pemilik dan aparat desa yang memiliki hak dalam mempertimbangkan pengambilan keputusan yang berkaitan dengan Lilifuk.

Hak mengakses pada zona Lilifuk adalah untuk kegiatan pariwisata, pendidikan, dan penelitian. Masyarakat tidak memiliki hak untuk mengakses terhadap zona Lilifuk untuk mencegah terjadinya pengrusakan dan pencurian. Hak pemanfaatan di zona Lilifuk hanya untuk pemiliknya. Hak pemanfaatan bagi pemilik dilakukan pada 
zona Lilifuk untuk budidaya rumput laut, sedangkan masyarakat tidak berhak memanfaatkan wilayah Lilifuk kecuali pada saat wilayah tersebut dibuka atau panen (Gambar 1). 63\% responden menyatakan bahwa masyarakat hanya sebagai pemanfaat saat panen atau saat Lilifuk dibuka. Masyarakat sekitarnya mengawasi dan memelihara Lilifuk tersebut dengan menjaga batas-batas yang telah disepakati yaitu pagar-pagar laut pada zona Lilifuk.

Selain itu masyarakat juga menjaga dan mengawasi kawasan perairan sekitarnya dengan tidak merusak terumbu karang dan padang lamun pada saat penangkapan ikan, serta menegur dan memberikan laporan kepada Pokmaswas dan aparat desa bila terdapat hal-hal yang merusak sumber daya perikanan. Berdasarkan hasil survey seperti pada Gambar 1, 13,3\% responden memberikan respon bahwa masyarakat terlibat dalam menjaga kelestarian Lilifuk, sedangkan $23,3 \%$ responden menyatakan bahwa masyarakat tidak memiliki peran atau keterlibatan apapun dalam Lilifuk (Gambar 1).

\section{Analisis Keberlanjutan Lilifuk}

Beberapa manfaat dapat diperoleh oleh masyarakat dari Lilifuk ini, baik manfaat secara ekonomi, sosial maupun lingkungan. Manfaat ekonomi yang dirasakan oleh masyarakat adalah manfaat untuk individu maupun rumah tangganya karena dapat menambah penghasilan dari penangkapan ikan pada saat buka Lilifuk. Manfaat sosial dirasakan oleh masyarakat untuk kehidupan kelompok atau lingkungan sosialnya seperti meningkatkan hubungan sosial antara satu rumah tangga dengan rumah tangga lainnya serta menjaga hubungan sosial dengan tetangga sekitarnya yang ikut pada waktu buka Lilifuk, bahkan dengan masyarakat di luar desa tersebut. Manfaat sosial lainnya adalah waktu buka Lilifuk memberikan hiburan gratis bagi masyarakat dengan berekreasi menonton acara buka Lilifuk tersebut. Selain itu, Lilifuk menjaga tradisi setempat karena Lilifuk merupakan warisan orang tua. Selain itu, Lilifuk ini memberi manfaat menjaga budaya daerah setempat karena pada saat dibukanya dilakukan pesta adat yang menampilkan acara-acara seni setempat (Tabel 4).

Lilifuk ini juga memberikan manfaat bagi lingkungan ekologinya. Dengan menerapkan penutupan Lilifuk selama setahun, maka ikan yang ada di sekitarnya ikut terjaga. Ikan akan terlebih dahulu besar dan memijah sehingga keberlanjutan sumber daya ikan terjaga, disamping sumber daya perikanan lainnya. Dengan adanya Lilifuk, masyarakat akan menjaga lingkungannya dengan baik dengan tidakmembuang sampah sembarangan di laut dan pantai dan tidak menggunakan alat tangkap yang merusak sumber daya. Berdasarkan hal tersebut, masyarakat menyadari pentingnya keberadaan Lilifuk dengan segala manfaatnya yang langsung dirasakan oleh mereka. Keberlanjutan Lilifuk akan selalu dijaga oleh masyarakat, karena dengan merusaknya berarti masyarakat akan mendapatkan dampaknya juga. Oleh karena itu masyarakat berusaha untuk menjaga kawasan perairan di sekitar Lilifuk baik dari dalam lingkungan maupun dari luar lingkungannya.

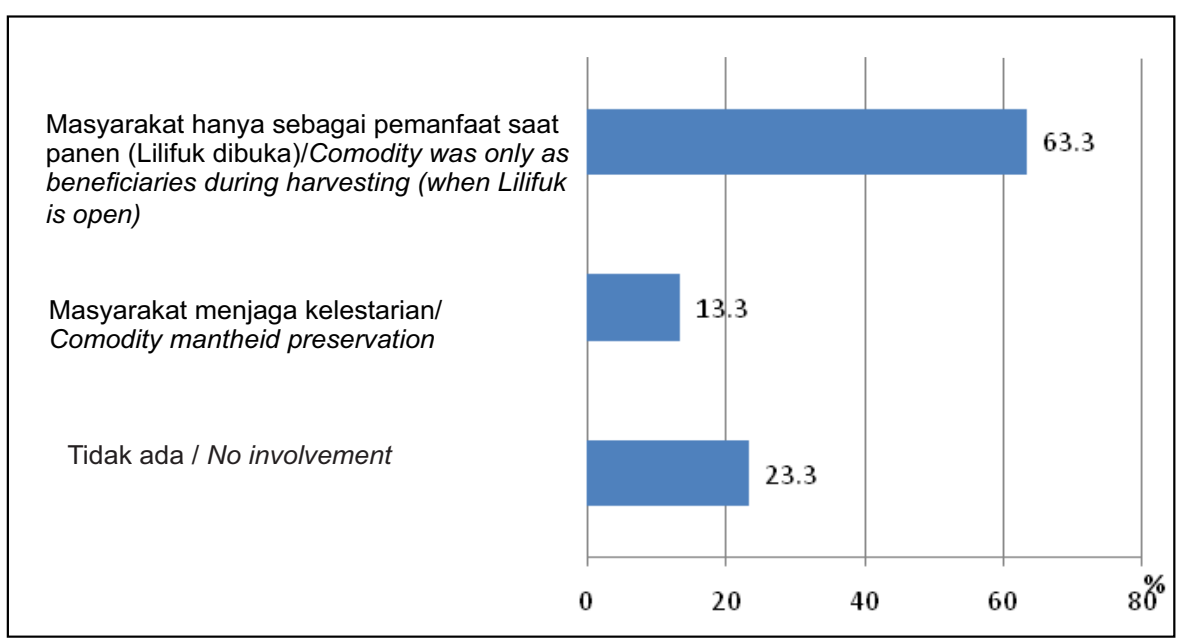

Gambar 1. Respon Responden Terhadap Keterlibatan Masyarakat dalam Lilifuk.

Figure 1. Respond of the Respondents on Community Involvement in Managing Local Wisdom of Lilifuk.

Sumber: Data primer diolah (2012) / Sources: Primary data proceed (2012) 
Tabel 4. Persepsi Masyarakat Mengenai Manfaat Lilifuk untuk kehidupannya.

Table 4. Communities Perception Regarding Benefits of Lilifuk for Their Daily Live.

\begin{tabular}{|c|c|c|c|}
\hline $\begin{array}{l}\text { Nomorl } \\
\text { Number }\end{array}$ & $\begin{array}{c}\text { Manfaat Lilifuk I } \\
\text { Benefits of Lilifuk }\end{array}$ & $\begin{array}{l}\text { Frekuensi/ } \\
\text { Frequency (n) }\end{array}$ & $\begin{array}{c}\text { Persentase/ } \\
\text { Percentage (\%) }\end{array}$ \\
\hline 1 & $\begin{array}{l}\text { Menambah penghasilan / } \\
\text { Additional income }\end{array}$ & 28 & 93.3 \\
\hline 2 & $\begin{array}{l}\text { Menjalin hubungan sosial/ } \\
\text { Liaise social relationship }\end{array}$ & 11 & 36.7 \\
\hline 3 & Rekreasi / Recreation & 7 & 23.3 \\
\hline 4 & $\begin{array}{l}\text { Sumber daya ikan tetap terjaga/ } \\
\text { Prevent fisheries resources }\end{array}$ & 8 & 26.7 \\
\hline 5 & $\begin{array}{l}\text { Lingkungan terjaga/ } \\
\text { Protect environment }\end{array}$ & 15 & 50 \\
\hline 6 & $\begin{array}{l}\text { Menjaga tradisi atau budaya/ } \\
\text { Preserve tradition or culture }\end{array}$ & 6 & 20 \\
\hline
\end{tabular}

Sumber: Data primer diolah (2012) / Sources: Primary data proceed (2012)

Masyarakat di sekitar Lilifuk berusaha menjaga lingkungan pesisir karena sebagian besar wilayah perairan tersebut digunakan masyarakat untuk usaha penangkapan ikan yang merupakan mata pencaharian utama masyarakat. Apabila lingkungan tidak dijaga maka akan berdampak pada produksi penangkapan ikan. Namun begitu, beberapa hal yang tidak dapat dihindari oleh masyarakat yang dapat mengancam sumber daya perairan di sekitar Lilifuk dan pengelolaannya baik pengaruh dari luar maupun dari dalam. Tabel di bawah menunjukkan secara rinci mengenai hal-hal yang dianggap sebagai ancaman terhadap sumber daya serta kualitas lingkungan pesisir dan juga ancaman terhadap keberlanjutan Lilifuk berdasarkan persepsi masyarakat.
Pertanyaan rinci yang diajukan kepada responden lebih jauh memberikan gambaran mengenai persepsi masyarakat akan kegiatan industri kelautan dan kegiatan yang berkaitan sumberdaya laut. Berikut ini adalah butir-butir yang mencerminkan sikap dan persepsi tersebut:

- Lahan perairan semakin sempit karena adanya rakit-rakit budidaya rumput laut oleh masyarakat dan adanya larangan yang dibuat oleh perusahaan budidaya mutiara

- Pencemaran limbah cucian dari perusahaan budidaya mutiara tersebut

- Perairan semakin kotor dan tercemar dari beberapa kegiatan lainnya. Permasalahan utama adalah minyak dan pembuangan

Tabel 5. Faktor-faktor Ancaman terhadap Pengelolaan Sumber Daya Perairan di Lilifuk di Kupang Barat Menurut Persepsi Masyarakat

Table 5. Threat Factors to Resources Management of Lilifuk According to Communities Perception.

\begin{tabular}{|c|c|c|c|}
\hline $\begin{array}{l}\text { Nomorl } \\
\text { Number }\end{array}$ & $\begin{array}{c}\text { Permasalahan Utama/ } \\
\text { Main Issues }\end{array}$ & $\begin{array}{l}\text { Frekuensi/ } \\
\text { Frequency }(\mathrm{n})\end{array}$ & $\begin{array}{l}\text { Persentase/ } \\
\text { Percentage (\%) }\end{array}$ \\
\hline 1 & Lahan sempit / Incapacious area & 12 & 40 \\
\hline 2 & $\begin{array}{l}\text { Produksi menurun / Production } \\
\text { decreased }\end{array}$ & 8 & 27 \\
\hline 3 & $\begin{array}{l}\text { Perairan tercemar atau terganggu/ } \\
\text { Waters polluted or disturbed }\end{array}$ & 7 & 23 \\
\hline 4 & $\begin{array}{l}\text { Tidak dijaga atau dilindungi / } \\
\text { Not guarded or protected }\end{array}$ & 1 & 3 \\
\hline 5 & Tidak tahu / Abstain & 2 & 7 \\
\hline & Total / Total & 30 & 100 \\
\hline
\end{tabular}

Sumber: Data primer diolah (2012) / Sources: Primary data proceed (2012) 
sampah sembarangan

- Ikan-ikan di perairan berkurang dan kerusakan terumbu karang

Selain manfaat dan kendala dalam Lilifuk, mekanisme pengambilan keputusan dalam Lilifuk juga penting dalam keberlanjutan Lilifuk. Hal ini akan mempengaruhi masyarakat untuk mengambil sikap dalam mendukung keberlanjutan atau sebaliknya menghilangkan Lilifuk. Sebanyak $73 \%$ responden memiliki persepsi bahwa mekanisme pengambilan keputusan belum tepat karena mekanisme Lilifuk hanya menurut pemilik semata. Menurut mereka pula, mekanisme seharusnya dibentuk bersama tokoh adat, tokoh agama dan pemerintah dengan dimusyawarahkan bersama untuk mendapat keputusan yang tepat bagi kepentingan bersama.

Sayangnya, dalam pelaksanaan pengelolaan Lilifuk ini tidak ada zona inti di dalamnya yang dapat menjaga kelestarian sumber daya secara berkelanjutan. Setiap tahun Lilifuk dibuka, semua wilayah pengelolaan tersebut dimanfaatkan oleh masyarakat (tidak ada pembagian zona inti, zona penyangga dan zona pemanfaatan) meskipun dengan menggunakan alat tangkap yang sederhana dan ramah lingkungan (serok dan tombak). Perdes yang sedang disusun oleh pemerintah desa atas keinginan masyarakat yang didukung oleh Lembaga Swadaya Masyarakat (LSM) setempat menginisiasi zona inti yang harus dikelola dalam Lilifuk.
Lilifuk memiliki manfaat yang cukup besar bagi masyarakat, maka perlu dipikirkan bagaimana menjaga keberlanjutan Lilifuk. Menurut persepsi masyarakat, beberapa faktor yang harus diperhatikan sebagai prioritas adalah menjaga dan melindungi serta memperbaiki kelestarian lingkungan, adanya dukungan dan pengawasan pemerintah, menerapkan aturan dan sanksi hukum, meningkatkan kesadaran masyarakat mengenai kelestarian, serta menggunakan alat tangkap ramah lingkungan (Gambar 2). Dalam rangka pencapaian keberlanjutan Lilifuk tersebut, beberapa hal harus dilakukan bersama-sama baik oleh masyarakat, pemerintah maupun tokoh-tokoh masyarakat seperti tetua adat dan tokoh agama.

Berdasarkan persepsi masyarakat mengenai aspek prioritas dalam menjaga keberlanjutan Lilifuk seperti yang terilustrasi pada Gambar 2, bahwa sebanyak $31 \%$ responden menyatakan bahwa masyarakat harus menjaga dan melindungi kelestarian serta memperbaiki lingkungan merupakan prioritas utama untuk menjaga keberlanjutan Lilifuk. Masyarakat belum menyadari secara menyeluruh pentingnya pengelolaan sumber daya berkelanjutan bagi kehidupannya di masa depan. Banyaknya pencurian ikan di kawasan Lilifuk menyebabkan masyarakat berpendapat pentingnya aspek tersebut untuk lebih diperhatikan.

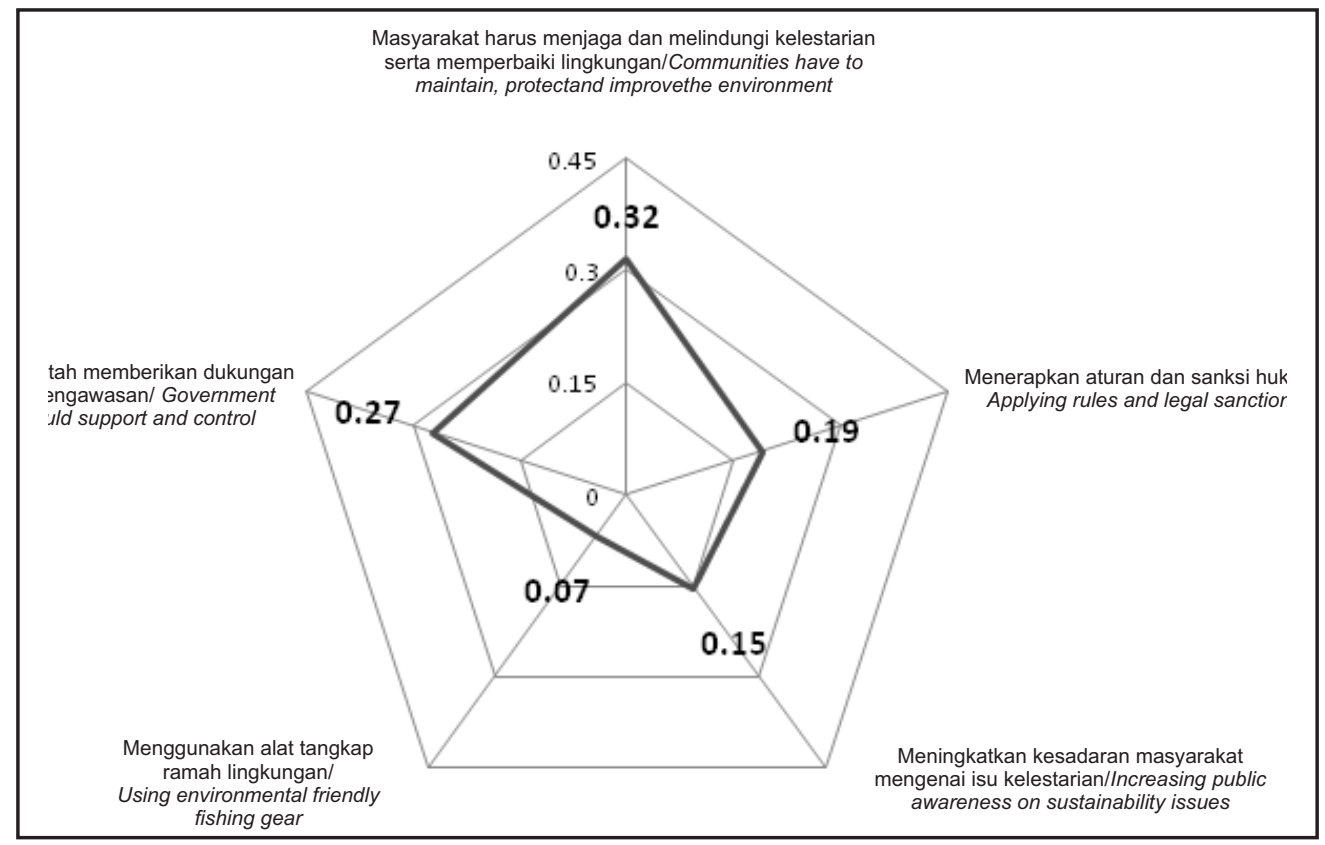

Gambar 2. Persepsi Masyarakat mengenai Aspek Prioritas dalam Menjaga Keberlanjutan Lilifuk. Figure 2. Communities Perception on the Sustaining the Lilifuk Prioritazion.

Sumber: Data primer diolah (2012) / Sources: Primary data proceed (2012) 
Dukungan dan pengawasan pemerintah diperlukan dalam keberlanjutan Lilifuk merupakan prioritas kedua menurut masyarakat dengan jumlah responden sebanyak $27,3 \%$, karena menurut pendapat masyarakat bahwa perhatian pemerintah daerah masih kurang dalam menjaga kelestarian Lilifuk. Sebagai contoh, sampai saat ini hanya ada satu Lilifuk yang memiliki Peraturan Desa (PERDES) mengenai Lilifuk yaitu di desa Kuanheum. Lebih lanjut, sebanyak 19,1\% responden menyebutkan perlunya penerapan aturan dan sanksi hukum yang tegas, sehingga pelanggaran terhadap aturan yang telah disepakati harus diberi sanksi sesuai dengan aturan yang telah disepakati. Hal ini sejalan dengan persepsi masyarakat mengenai penangkapan ikan dengan menggunakan alat tangkap yang ramah lingkungan (sebanyak 6,7\% responden). Selama ini, alat tangkap ramah lingkungan seperti serok dan tombak digunakan pada saat buka Lilifuk, hanya saja masih banyak penggunaan alat tangkap yang merusak lingkungan yang digunakan di perairan sekitar Lilifuk seperti bom, racun dan pukat garu.

\section{KESIMPULAN DAN IMPLIKASI KEBIJAKAN}

\section{Kesimpulan}

Lilifuk dapat bermanfaat secara berkelanjutan bagi masyarakat baik secara ekonomi, sosial maupun lingkungannya namun harus memperhatikan aspekaspek pengelolaan yang berkelanjutan. Masyarakat lokal yang terlibat dan yang mendapatkan dampak dari pengelolaan tersebut baik langsung maupun tidak langsung dapat berperan serta memberikan kontribusi yang nyata dalam menjaga keberadaan Lilifuk. Berdasarkan persepsi tersebut diperoleh cara pandang masyarakat mengenai pentingnya Lilifuk untuk kelestarian sumber daya dalam menopang kehidupannya, dan bagaimana masyarakat menjaga keberadaannya sehingga dapat terus dimanfaatkan secara keberlanjutan.

Manfaat Lilifuk bagi masyarakat berdasarkan persepsinya adalah menambah penghasilan (93\%), menjalin hubungan sosial $(367 \%)$, rekreasi $(23,3 \%)$, menjaga sumber daya ikan $(26,7 \%)$, menjaga lingkungan (50\%) dan menjaga tradisi atau budaya (20\%). Faktor-faktor ancaman terhadap Lilifuk berdasarkan persepsi masyarakat adalah lahan sempit (40\%), produksi menurun $(27 \%)$, perairan tercemar $(23 \%)$ dan tidak dijaga (3\%). Prioritas utama dalam menjaga keberlanjutan Lilifuk berdasarkan urutannya adalah 1. Menjaga dan melindungi serta memperbaiki kelestarian lingkungan $(31,6 \%), 2$. Dukungan dan pengawasan pemerintah $(27,3 \%)$, 3. Menerapkan aturan dan sanksi hukum (19,1\%), 4. Meningkatkan kesadaran masyarakat mengenai kelestarian (15,3\%), dan 5. Menggunakan alat tangkap ramah lingkungan $(6,7 \%)$.

\section{Implikasi Kebijakan:}

- Menekankan pentingnya zona inti di dalam pengelolaan Lilifuk untuk menjaga kelestarian sumber daya

- Diperlukan upaya penyadaran masyarakat mengenai pentingnya pengelolaan sumberdaya berkelanjutan untuk manfaat yang berkelanjutan bagi masyarakat di sekitarnya

- Dukungan pemerintah daerah dalam penguatan regulasi dan pengawasan sumber daya serta pelestarian tradisi dan budaya

- Menerapkan aturan dan sanksi yang tegas terhadap orang yang melanggar pengelolaan Lilifuk.

\section{DAFTAR PUSTAKA}

Boikh, L.I. 2010. Persepsi Masyarakat Terhadap Daerah Perlindungan Laut Berbasis Masyarakat dengan Kearifan Lokal di Desa Bolok. Skripsi. Fakultas Perikanan dan IImu Kelautan Universitas Kristen Artha Wacana. Kupang, Nusa Tenggara TImur. 83 hal.

Fauzi, A. 2004. Ekonomi Sumber Daya Alam dan Lingkungan. Teori dan Aplikasi. Jakarta: PT. Gramedia Pustaka Utama. 259 hal.

Idrus, M. 2009. Metode Penelitian Sosial. Pendekatan Kualitatif dan Kuantitatif. Edisi Kedua. Jakarta: Penerbit Erlangga. 266 hal.

Keraf, A.S. 2010. Etika Lingkungan Hidup. Jakarta: Penerbit Buku Kompas. 408 hal.

Mitchell, B., B. Setiawan \& H.R. Dwita. 2000. Pengelolaan Sumber daya dan Lingkungan. Yogyakarta: Gajah Mada University Press. 498 hal.

Nikijuluw, C. 2001. Aspek Sosial Ekonomi Masyarakat Pesisir dan Strategi Pemberdayaan Mereka dalam Konteks Pengelolaan Sumberdaya Pesisir secara Terpadu dalam Prosiding Pelatihan Pengelolaan Wiyalah Peisisr Terpadu. Pusat Kajian Sumber Daya Pesisir dan Lautan Institut Pertanian Bogor: 14-27. 
Nikijuluw, V.P.H. 2002. Rezim Pengelolaan Sumber Daya Perikanan. Jakarta: Pustaka Cidesindo. 254 hal.

Sitorus, M.T.F. 1998. Penelitian Kualitatif: Suatu Perkenalan. Kelompok Dokumentasi IImu Sosial IPB. Bogor. 73 hal.

Sugandhy, A. \& R. Hakim. 2007. Prinsip Dasar Kebijakan Pembangunan Berkelanjutan Berwawasan Lingkungan. Jakarta: Penerbit Bumi Aksara. 157 hal.
Yulianto, G. 2008. Kajian Kelembagaan Hak Ulayat Laut di Desa-Desa Pesisir Teluk Bintuni. Buletin Ekonomi Perikanan Volume VIII (2): 82-89. 